\title{
Vliv lidské činnosti na geologii a geomorfologii krajiny
}

\section{Simona Dvořáčková}

Envigogika 8 (5) - Recenzované články/ Reviewed Papers

Publikováno/Published 31. 12. 2013

DOI: $\underline{10.14712 / 18023061.402}$

\begin{abstract}
Abstrakt
V souladu s koncepcí environmentální výchovy, zabývající se povědomím o vztazích člověka k okolnímu prostředí, je nezbytné věnovat se také vlivu lidské společnosti na neživou složku prostředí - na geologické procesy, charakteristiky nově vznikajících hornin a geomorfologii krajiny. $V$ současné době dosahuje lidská činnost takové míry, že přebírá roli významných geologických procesů, avšak s tím rozdílem, že člověk jako geologický činitel působí na zemský povrch mnohem rychleji. $Z$ tohoto důvodu se čím dál častěji hovoří o novém geologickém období - antropocénu. Tento článek je zaměřený především na vzdělavatele v environmentální výchově. Objasňuje problematiku antropocénu a zároveň poskytuje přehled nejvýznamnějších dopadů lidské společnosti na geosféru, doplněný o návrhy výukových aktivit.
\end{abstract}

\section{Klíčová slova}

vliv lidské společnosti na prostředí; geologické procesy; georeliéf, antropocén; výukové aktivity

Impact of human activity on geology and geomorphology of the landscape

\begin{abstract}
In accordance with the concept of environmental education focused on awareness of humanenvironment relationships, it is essential to also consider the impacts of human society on geological processes, and the characteristics of newly forming rock material and geomorphology within the landscape. Human activity is currently reaching such a degree that it exceeds the rate and extent of some natural geological processes, only with the difference that humans are making an impact on the earth's surface much faster. That is why the new Anthropocene epoch is mentioned more frequently. The article is aimed mainly at environmental education teachers and tutors. It clarifies the issue of Anthropocene and provides an overview of the main impacts that humanity has on the geosphere, supplemented with proposals for teaching activities.
\end{abstract}

\section{Keywords}

human society impact on environment; geological processes; geomorphology; Anthropocene; teaching activities 


\section{Úvod}

Horniny představují geologický záznam obsahující informace o prostredí a jeho změnách $v$ době jejich vzniku během geologických období. Všechny sedimentární horniny nesou určité množství informací nejen o geologických procesech $v$ danou dobu na daném místě probíhajících, ale i o klimatu, oceánském a atmosférickém proudění, pohybech zemské kůry, geologických procesech a biodiverzitě. Stejným způsobem budou po následující geologická období zachovány i současné změny prostředí, jejichž původcem je právě člověk.

Už ve druhé polovině 19. století si začali někteří vědci uvědomovat, že lidská aktivita přebírá úlohu geologických a geomorfologických procesů Země. Jako první se toto období pokusil pojmenovat Stoppani, který v roce 1873 mluvil o éře "antropozoika" jako o období, kdy je síla lidské aktivity srovnatelná se "zemskými silami" (Crutzen \& Stoermer, 2000). S tímto názorem souhlasí i současní vědci. Podle Price et al. (2011) se tak člověk stal jedním z významných exogenních geologických činitelů ovlivňujících erozi, transport a ukládání materiálu. Syvitsky (2012) srovnává vliv člověka na zemský povrch s globálním zaledněním, avšak s tím rozdílem, že člověk přetvořil povrch v několika málo stoletích, zatímco zalednění $\mathrm{k}$ tomu potřebovalo výrazně delší dobu.

K pojmenování tohoto člověkem dominovaného období se vrátil až $v$ roce 1992 reportér deníku New York Times Andrew Revkin, který v knize nazvané Globální oteplování navrhl název "antrocén". Ten se však neujal. Od roku 2000 se ale velmi často skloňuje jiný výraz - "antropocén" (Crutzen \& Stoermer, 2000). Tento termín nabírá na své popularitě obřím tempem, a to převážně i díky značné popularitě a dostupnosti informačních médií. Každým rokem vyjdou desítky až stovky odborných článků na toto téma. IUGS (Mezinárodní unie geologických věd) dokonce založila skupinu odborníků, která má rozhodnout, od kterého roku se bude antropocén oficiálně datovat a jaký charakter má mít hraniční vrstva hornin rozdělující antropocén od staršího holocénu (Stromberg, 2013). Pro hledání této hraniční vrstvy a stanovení přechodu do nového geologického období je však nutné posoudit zejména geologické dopady lidské činnosti, respektive dopady na charakter vznikajících hornin.

\section{Stanovení počátku antropocénu}

Podle některých názorů by měl být počátek antropocénu spjat s prvními zemědělskými aktivitami moderního člověka už na začátku holocénu (Smith \& Zeder, 2013), kdy mýcení lesů, domestikace hospodářských zvíratat a zavlažování ploch s plodinami vedlo k rapidnímu zrychlení eroze a globálnímu nárůstu koncentrací oxidu uhličitého a metanu v ovzduší. Podle jiných by se počátek antropocénu měl datovat až $\mathrm{s}$ nástupem průmyslové revoluce $\mathrm{v}$ první polovině 19. století (Steffen et al., 2007), kdy se začala ve velké míre využívat fosilní paliva a železné rudy, vzrostla populace a začala se rozvíjet infrastruktura. Od roku 1850 by podle Steffena a kol. (2007) bylo možné rozlišit tři fáze antropocénu: První (1800-1945) souvisí $\mathrm{s}$ počátky industrializace, rozšířením využívání fosilních paliv, vynálezem parního stroje, rozvojem železnic a kovovýroby a vynálezem dusíkatých hnojiv. Druhá (1945- cca 2015?) je ve znamení rapidní akcelerace antropogenních aktivit a dopadů podmíněných nárůstem populace, motorových vozidel, elektrických a elektronických zařízení, konzumerismu a globalizace. Třetí fázi promítá Steffen a kol. (2007) do blízké budoucnosti, ve které optimisticky předpokládá větší environmentální uvědomění lidské společnosti, změnu v chování a hodnotách, zavedení politických a ekonomických opatření a omezování škod na nejnižší možnou míru. I kdyby však třetí fáze proběhla v takto pozitivním duchu, je třeba si uvědomit, že některé změny jsou již nevratné (například chemické alterace již uložených 
sedimentů), u jiných je třeba počítat se značným časovým prodlením (například zpomalení oteplování a acidifikace mořské vody).

Sedimentární vrstva, která by pomohla oficiálně stanovit statigrafickou hranici mezi holocénem a antropocénem, se stále hledá. Někteří vědci se domnívají, že tuto hranici by mohly představovat celosvětově rozšířené, ale prostorově roztroušené vrstvy sedimentů se zvýšenou koncentrací uhelného popela a prachu, související s nástupem průmyslové těžby uhlí po roce 1850 (Stinchcomb et al., 2013). Jiní ji vidí v geochemických znacích, např. $\checkmark$ nárůstu koncentrací atmosférického oxidu uhličitého a metanu od začátku průmyslové revoluce (Steffen et al., 2007) nebo $v$ nárůstu koncentrace radioaktivních izotopů po jaderných výbuších $\vee$ roce 1945 (Zalasiewicz et al., 2011) či v nárůstu koncentrací dusíkatých residuí z hnojiv, polycyklických aromatických uhlovodíků, syntetických chemikálií a jiných látek běžně používaných ve druhé polovině a ke konci 20. století (Doney, 2010).

Snaha nalézt hraniční vrstvu, která by $v$ geologickém měřítku odlišila posledních 200 let, je jako hledání jehly v kupce sena. Autin a Holbrook (2012) ale stř́zlivě připomínají, že nové geologické období by mělo být uznáno až na základě nezvratných stratigrafických kritérií a důkazů, nikoliv obráceně, jak se momentálně děje: termín antropocén se ujal a teprve nyní se hledají sedimentární sledy s charakteristikami, které by mohly být použity pro vyznačení jeho počátku.

\section{Budoucnost antropocénu}

Dalším velkým otazníkem v diskusi o antropocénu zůstává skutečnost, jak budou jeho znaky zachovány do budoucnosti v rámci geologického času. Většina horninových vrstev, na kterých je založena stratigrafie předchozích geologických období, je tvořena stlačenými sedimenty (u některých typů sedimentů, např́klad u uhlí, se jedná o stlačení dokonce v poměru 10:1, Ryer and Langer, 1980). Nicméně i tenká anomální souvislá vrstva může být z časového hlediska významná stejně jako např́klad iridiová vrstva vzniklá při dopadu bolidu na přelomu druhohor a třetihor.

Míra zachování hornin antropocénu bude záležet na kombinaci a poměru antropogenních a prírodních procesů jako je rychlost pohřbení, přepracování a recyklace materiálu nebo mechanická a chemická eroze. Vzhledem $k$ tomu, že mořské sedimenty se zachovávají lépe než kontinentální (díky eliminaci zvětrávání), mají větší šanci na zachování antropogenní materiály $v$ prímořských oblastech (města, př́stavy), které budou po vzestupu mořské hladiny rychle překryty sedimentem (Price et al., 2011). V kontinentálním prostředí mají největší naději na zachování místa, která mohou být rychle zakryta jemnozrnným sedimentem (např́klad sopečným popelem, bahnotoky). Velmi pravděpodobné je $\mathrm{i}$ zachování hlubinných úložišt́ jaderných odpadů, která se situují do pevných hornin $v$ geologicky stabilních oblastech a zalévají betonem. Určité šance mají i podzemní prostory a stavby jako podzemní dráhy či Eurotunel pod kanálem La Manche (Weisman, 2009).

Způsob a doba zachování jednotlivých materiálů bude záležet na prostředí, podnebí a rychlosti zakrytí novými sedimenty. Zatímco teplé a humidní klima zvyšuje intenzitu chemického zvětrávání a rychlost průběhu rozkladných a korozivních reakcí, chladné a suché klima je pro dlouhodobé zachování materiálu přiznivější. Doba zachování bude závislá na expozici vưči vodě a kyslíku. Materiály rychle překryté drobnozrnným sedimentem nebo cíleně uložené pod povrchem se zachovají lépe než ty na povrchu. Záležet bude také na velikosti objektu. Větší šance na zachování budou mít masivnější materiály oproti drobným či tenkostěnným. $V$ neposlední řadě bude záležet na samotném složení antropogenního materiálu a na tom, $v$ jakém prostředí se ocitnou, respektive jak blízké bude chemické 
složení okolního prostředí složení samotného objektu. Nejlépe by se mohl po rychlém zakrytí sedimentem zachovat beton uložený $v$ podzemních prostorách, i když také u něj bude záležet, jaký materiál byl použit na jeho výrobu. I ten ale bude časem umožňovat migraci fluid, rozpouštění a následnou krystalizaci minerálních látek. $Z$ dosud provedených studií vyplynulo, že některé méně stabilní minerály běžně se $v$ betonu vyskytující jsou již po krátké době nahrazeny jinými, stabilnějšími (Laciok et al., 2005). Betonové stavby na zemském povrchu poměrně rychle podlehnou kombinaci chemického, mechanického a biologického zvětrávání. Železo podléhá korozi a to zhruba rychlostí $0,3 \mu \mathrm{m} /$ rok (Johnson \& Francis, 1980), což znamená, že masivnější kontejnery používané na odpad by mohly vydržet kolem 100000 let (Alexander \& McKinley, 1992). Po kompletní korozi, vyloužení a přesunu iontů do okolního prostoru by po železném materiálu zůstal volný prostor (který by byl vyplněn sekundárními nerosty vykrystalovanými z migrujících roztoků) a rezavé zbarvení okolních hornin. Sklo za př́stupu vzduchu podléhá stejnému chemickému zvětrávání jako ostatní minerály silikátové skupiny, tj. časem u nich dojde $\mathrm{k}$ vyloužení iontů sodíku, vápníku a křemíku a v místě původního skla by zůstal hliník (Manichev et al., 2005). Podobný proces probíhá při rozpadu živců za vzniku Al-bohatých jílových nerostů. Chování materiálů obsahujících těžké kovy nebo nerezové oceli zatím nelze zatím odhadnout. Zřejmě se časem začlení do biogeochemických reakcí podporovaných migrujícími roztoky v horninách a podílí se na tvorbě druhotných minerálů vtroušených v okolních horninách. Umělé hmoty se mohou působením dlouhého geologického času a zvýšené teploty a tlaku rozložit na prírodní uhlovodíky (Weisman, 2009). V případě rychlého zakrytí jemnozrnným sedimentem může dojít k zachování $\mathrm{i}$ jiných odolných antropogenních předmětů, a to $v$ podobě otisků, fosilních artefaktů nebo - pokud dojde $\mathrm{k}$ jejich následnému rozkladu - k lokálně zvýšeným chemickým anomáliím (Zalasiewicz, 2012).

Tak jako jsou v sedimentárních horninách minulých geologických období zachovány fosilie organismů, mohou i dnes vznikající sedimenty nést do budoucnosti doklad o současné člověkem ovlivněné biodiverzitě. To se týká především pylů, které poukazují na převahu zemědělských plodin nad planě rostoucími rostlinami. Kostry domestikovaných a užitkových zviřat se nejspíš nedochovají, protože většinou končí v kafilériích, nebo v mělkých hrobech, kde moc šancí na fosilizaci není. Stejné je to i s ostatky člověka - k jejich zachování dojde spíš náhodou při prírodních katastrofách (pohřbení $v$ sopečném popelu a prachu, bahnotocích), nehodách (utonutí $v$ rašeliništích) či místech násilných činů (pohřbení v cementu) (Zalasiewicz, 2012).

Hlavním př́nosem současné celosvětové diskuse o zavedení antropocénu je jeho popularizace a medializace. Díky tomu se dostává $\mathrm{k}$ široké veřejnosti množství informací o dopadech působení lidské společnosti na prostředí ve svém úplném pojetí, tzn. včetně vlivu na geosféru $v$ rámci geologického času. Doposud byly totiž tyto informace doménou odborných oborů jako antropogenní geologie nebo environmentální geologie.

\section{Environmentální výchova a výuka dopadů člověka na horninové prostředí a procesy}

$\checkmark$ environmentální výchově jsou $v$ souvislosti s dopady lidské společnosti na okolní prostředí diskutovány převážně globální klimatické změny, změny ekosystémů a znečištění prostředí, či stále se zvyšující spotřeba surovin, potravin a vody pro narůstající populaci. Z mnohých výzkumů a studií provedených mezi žáky základních a středních škol, ale i vysokých škol $s$ pedagogickým zaměřením na výuku prírodopisu, zeměpisu a environmentální výchovy vyplývá, že geologická témata se řadí k nejméně oblíbeným z prrírodních věd školního kurikula (Dvořáčková \& Ryplová, 2012). Absence zájmu a některé 
zjištěné znalostní nedostatky mohou u žáků vzbuzovat mylnou představu, že geosystémy jsou mnohem odolnější vưči antropogenním změnám, než ostatní ekosystémy. Málokterý žák si navíc uvědomuje, do jaké míry je jeho moderní konzumní život závislý na nerostných surovinách, nebo jak významně je biodiverzita závislá na geodiverzitě (pestrosti horninového složení). Je proto nezbytné inspirovat vzdělavatele působící v environmentální výchově, aby se věnovali také antropogenním vlivům na horninové prostředí a geologické pochody. Následující text poskytuje přehled nejvýznamnějších dopadů lidské společnosti na geosféru, včetně několika návrhů na výukové aktivity. Geologické dopady lidské činnosti

Vliv člověka na geologii a geomorfologii krajiny souvisí převážně s těžbou nerostných surovin, jejich přemistóváním, zpracováním a hromaděním na místech jiných. Tyto činnosti ve své podstatě nahrazují prírodní geologické pochody, jako je eroze, transport a sedimentace, poprípadě i metamorfóza, čímž narušují jejich přirozený průběh. Přestože nejnápadnější vliv je spjat $s$ moderní dobou po průmyslové revoluci, vlivy podobného charakteru se dají sledovat už od dob, kdy lidstvo přešlo od životního stylu lovců a sběračů k zemědělství (Autin \& Holbrook, 2012). Mýcení a vypalování lesů, domestikace hospodářských zvírat a zavlažování ploch osetých zemědělskými plodinami (obzvláště rýže) vedla $\mathrm{k}$ urychlení eroze a podle některých názorů i k ranému globálnímu nárůstu koncentrací atmosférického oxidu uhličitého a metanu, které zamezilo príchodu další doby ledové (Ruddiman, 2003; Ruddiman \& Thompson, 2001). Od doby kamenné se začínají cíleně těžit některé nerostné suroviny jako křemité materiály používané na výrobu pazourků, grafit, keramické jíly, později měd', cín, železo, zlato a stříbro (Jirásek et al., 2010). Zpracování nerostných surovin bylo většinou vázáno na řiční toky, čímž docházelo $\mathrm{k}$ alteraci skladby rríčních sedimentů. Vyvíjející se způsob těžby a zpracování nerostných surovin zanechávaly stopu i na morfologii terénu $v$ podobě jam, šachtic, pink, sejpů a hald. Díky přemistóování velkého množství hornin a materiálu se měnila význačným zpưsobem geomorfologie krajiny, stavby představují významné krajinné elevace. Např́klad na Cheopsovu pyramidu bylo potřeba 6,5 miliónů tun pískovcových kvádrů, na stavbu Velké čínské zdi 0,7 Gt hornin a hlíny. Vliv člověka se zintenzivnil s narůstající těžbou nerostných surovin ve středověku fosilní paliva se ve větším měřítku začala dobývat $v$ Číně $v 10$. století. Značný dopad na geologii a morfologii krajiny měl následný nárůst populace a $s$ ním zvýšená urbanizace, stavba infrastruktur, a zvýšení množství odpadu. Ke zintenzivnění antropogenního vlivu došlo po průmyslové revoluci a dramatická akcelerace nastala s nástupem konzumní společnosti po roce 1950 (Syvitski, 2012). Současné antropogenní geologické dopady se dělí na prímé a neprímé.

\section{Antropogenní materiály}

Přímé dopady moderní doby představují především novodobé stavební, průmyslové a odpadové materiály, které se stávají nedílnou součástí litosféry a jednou budou tvořit novou horninovou vrstvu se specifickými rysy. Soudobé antropogenní materiály jsou různorodé: urbánní konstrukce tvořené směsí materiálu prírodního (například cement, cihly, beton a asfalt) a umělého (sklo, umělé hmoty, slitiny kovů, popílek, škvára). Patří sem také podpovrchové konstrukce (piliře, potrubí), materiály tvořící odpady na skládkách, sedimenty usazené $v$ umělých vodních nádržích a tzv. technolity - nerosty a horniny vznikající vlivem působení člověka (strusky, výkvěty na omítkách, nerosty vznikající na hořících haldách, uměle pěstované krystaly a jiné). Řadí se sem ale i umělá podloží zastavěných ploch tvořená zbytky sutin, základů budov, sklepů, drenáží a odpadu, na kterých se staví nové budovy a generace měst.

\section{Substituce geologických procesů}

Nepř́mé dopady představují významné změny v průběhu a intenzitě geologických procesů, změny georeliéfu (převážně pevnin), narušení geochemických cyklů, početnosti 
a diverzity zachovaných fosilií a další. $K$ některým změnám dochází až druhotně, vlivem interakcí se znečištěnou vodou a ovzduším. Nepřímé dopady jsou mnohem rozmanitější než př́mé a jejich výčet je delší.

Jedním z nepř́mých dopadů je např́klad změna v intenzitě transportu hornin. Velké umělé vodní nádrže zadrží až $80 \%$ unášeného sedimentu (Syvitski \& Kettner, 2013), což vede ke snížení množství sedimentu přenášeného přehrazenými řekami. Se sníženým transportem říčního sedimentu do oceánů následně souvisí pokles říčních delt a zvýšená eroze kontinentálního šelfu. Na druhou stranu, množství člověkem remobilizovaných hornin $v$ souvislosti $s$ těžbou, výstavbou i zemědělstvím překračuje množství materiálu transportovaného přirozenými geologickými procesy (Zalasiewicz et al., 2011). Stavební činnost zase konkuruje přírodnímu usazování hornin, (například vybudování umělých ostrovů ve Spojených arabských emirátech a Singapuru, rozšíření pobřeží v San Francisku a Sydney, vybudování ostrovních letišt́ v Hongkongu, na Korfu a jinde (Matyášek \& Suk, 2009; Syvitsky \& Kettner, 2013)). S transportem hornin souvisejí i výrazné změny georeliéfu krajiny, kdy člověk vytvář́ elevace (výsypky a haldy, svým způsobem i výškové budovy), deprese (povrchové doly, lomy, krátery po výbuších), ale i zarovnaný povrch (zemědělské plochy, upravený povrch $v$ městských aglomeracích). Také odčerpáváním vody, ropy, či zemního plynu, poddolováním, nebo zatížením povrchu velkými městy a těžkými konstrukcemi dochází ke změnám georeliéfu, převážně k poklesům povrchu, vzniku sesuvů, depresí a v některých prípadech i propadů. Těžební činnost a destrukce zemského povrchu zase přebírá roli prírodní eroze a vede $\mathrm{k}$ tvorbě významných krajinných depresí. Dochází k odtěžení celých kopců ( $v$ ČR napríklad 200 m vysokého Chlumu u Haber, Matyášek a Suk, 2009) nebo vrcholků celého horského masívu (Kayford Mount $v$ Západní Virginii, USA). Nepřímé dopady na geologické procesy jsou způsobovány také antropogenním znečištěním atmosféry a hydrosféry. Kyselé deště vedou ke zrychlení prírodní chemické a mechanické eroze kontinentálních hornin a vzniku zvětralin. Mezi další geologické vlivy člověka patři antropogenní vyvolání zemětřesení (například při důlní činnosti, jaderných výbuších, provozu těžkých strojů), nebo metamorfní přeměny hornin pod tlaky velkých měst, jaderných výbuchů či vysokých teplot během petrurgických a metalurgických procesů.

\section{Změny ve složení přírodních hornin}

V důsledku lidské činnosti se mění i charakter nově vznikajících přírodních sedimentů. Četné umělohmotné látky jako polyetylen, polyester, polypropylen, akryl, polyvinylchlorid a další se rozpadají na menší části, které bývají začleňovány do ukládajícího se sedimentu a alterují jeho složení. Zvýšená míra kyselosti mořské vody vede $\mathrm{k}$ úbytku kalciformních korálů, $\mathrm{k}$ rozpouštění existujících vápnitých sedimentů mořského dna a jejich nahrazení jílovými sedimenty (Tyrell, 2011). Zvýšené množství dusíku, které se do oceánů dostává zejména splachem dusíkatých hnojiv ze zemědělských ploch, způsobuje eutrofikaci a tvorbu anoxického prostředí, následkem čehož vznikají na mořském dně jílové sedimenty tmavého zbarvení, které nasedají na starší světlé vápnité sedimenty. Oceánským vodám se navíc nedostává dostatečného množství rozpuštěného křemíku, protože ten je spotřebováván při tvorbě křemitých schránek diatomickým fytoplanktonem, kterému se velmi daří ve výše položených umělých přehradních nádržích (Tyrell, 2011).

Po průmyslové revoluci se začaly do okolního prostředí dostávat různé typy znečištujících látek, které vlivem rozličného působení biogeochemických cyklů alterují chemické složení sedimentů. Jedná se o polyaromatické uhlovodíky, celkové ropné uhlovodíky, polychrolované bifenyly, těžké kovy a jiné. Již dnes Ize $v$ jednotlivých sedimentárních horizontech vysledovat anomálie $v$ chemickém složení, jež časově korelují $s$ vývojem průmyslu a urbanizace moderní lidské společnosti. Např́klad ve vrstvách usazených po nástupu průmyslového období, kdy se začalo spalovat ve větší míře uhlí, se ve zvýšených 
koncentracích vyskytují polyaromatické uhlovodíky, zatímco vrstvy usazené $v$ druhé polovině 20. století vykazují zvýšené koncentrace celkových ropných uhlovodíků, které souvisí s přechodem na ropná paliva (Vane et al., 2011). Ve stejně starých vrstvách dochází ke zvýšení koncentrace některých těžkých kovů vznikajících kromě spalování fosilních paliv také během zpracování železa a neželezných kovů, výroby cementu, skla či chloru, zpracování odpadu a dopravy. Nejmladší testované vrstvy vykazují anomální koncentrace polychlorovaných bifenylů pocházejících z moderního chemického průmyslu (ibid.). $\mathrm{Na}$ chemické alteraci vápnitých sedimentů se navíc podílí jakákoliv anomálie ve složení vápnitých schránek kalciformních organismů. Ty totiž $\mathrm{k}$ vysrážení uhličitanu vápenatého začínají upřednostňovat místo ${ }^{13} \mathrm{C}$ lehči izotop uhlíku ${ }^{12} \mathrm{C}$, který nese znaky fosilních paliv (Raymo, 2013).

\section{Výukové aktivity}

Vliv člověka na geologii a geomorfologii krajiny by měl být nedílnou součástí environmentální výchovy. Přestože geologické i geomorfologické procesy jsou prostorově i časově velmi rozsáhlé, Ize jejich výuku zpestřit různými aktivitami. Návrhy výukových aktivit uvedených $v$ tomto článku mají za cíl podnítit u žáků pochopení vzájemné provázanosti lidské činnosti s geologickými procesy, uvědomit si míru využívání nerostných surovin $v$ běžném životě a dopady, které $s$ sebou přináší jejich těžba, zpracování a produkce odpadů. Cílovou skupinou mohou být jak žáci nižšího, tak vyššího stupně zš v závislosti na množství předpokládaných znalostí, poskytnutých informací a požadovaných výsledcích.

\section{Výuková aktivita č. 1: Změny v průběhu geologických procesů před a po prííchodu člověka}

Popis: Tato aktivita inspiruje žáky $\mathrm{k}$ zamyšlení o tom, jakých změn $v$ průběhu geologických procesů a složení doznalo prostředí s příchodem lidí.

Materiál: Mapy, obrázky nebo fotografie fiktivní nebo reálné oblasti, ze kterých si Ize udělat představu o topografii, říční síti, vegetačním krytu a horninovém podloží. Mapy, obrázky nebo fotografie stejné oblasti s vyznačenými antropogenními prvky: lidskými sídly, průmyslovými zónami, skládkami, umělými vodními nádržemi, zemědělskými plochami, těžebními oblastmi aj. Pro srovnání lze také použít historické a soudobé fotografie okolí místa bydliště, popř́padě si žáci mohou podle instrukcí namalovat své vlastní mapy např́klad fiktivního ostrova...

Postup: Žáci si pozorně prohlédnou první mapu oblasti, do které nezasáhl člověk, a snaží se identifikovat, jaké geologické procesy $v$ této krajině probíhají, co se děje $s$ horninami a co ovlivňuje reliéf (například říční eroze a transport, řícení horských svahů vlivem gravitace, mrazové zvětrávání, větrná eroze a transport, krasové zvětrávání vápencových oblastí atd.). U druhé mapy žáci usilují zjistit, jaké zásahy do horninového prostředí, reliéfu krajiny a intenzity průběhu geologických procesů způsobila prítomnost člověka. Zde mohou být zaznamenány jevy jako snížení množství říčního sedimentu vlivem zpevnění ŕíčních koryt a vybudování přehrad, těžba nerostných surovin a tvorba krajinných depresí, kontaminace vody, půdy a atmosféry vedoucí k rychlejšímu chemickému zvětrávání, zrychlení eroze vlivem odlesnění a pojezdu těžkou technikou, zarovnání nerovností reliéfu pro zemědělské plochy, zatížení horninového prostředí velkými stavbami, způsobení sesuvů, hromadění horninového materiálu a tvorba elevací v krajině, atd. Žáci mohou být rozděleni na menší skupiny, jejichž výsledné postřehy jsou na konci aktivity porovnány, sumarizovány a podrobněji diskutovány. Jako doplněk $\mathrm{k}$ tomuto cvičení si mohou žáci sami vyhledat na 
družicových snímcích velké povrchové doly, umělé ostrovy, rozsáhlé urbánní aglomerace, či jiné významné antropogenní prvky georeliéfu.

\section{Výuková aktivita č. 2: Uvědomění si míry závislosti na nerostných surovinách}

Popis: Každý člověk žijící moderním způsobem života denně využívá nesčetné množství předmětů, jejichž výroba je závislá na nerostných surovinách. Ve vyspělých zemích je téměř vše na dosah ruky a okamžitě dostupné, takže si člověk velmi často ani neuvědomuje, jak úzký je vztah všech předmětů denní potřeby $k$ neživé prírodě a bez čeho by se musel obejít, kdyby nerostné suroviny byly náhle vyčerpány. Tato aktivita vede žáky k zamyšlení se nad tím, kde se berou věci, kterými se obklopují akaždodenně je používají.

Materiál: žádný

Postup: Žáci by si měli během jednoho dne zaznamenávat všechny předměty, které použili, nebo se kterými přišli do styku. Seznam by měl obsahovat takové položky jako počítač, televize, mobilní telefon, dopravní prostředek, dům/byt/škola, papír, tužka, umělohmotné láhve, příbory, nádobí, hygienické př́pravky, potraviny, atd. Poté by si měli u každé položky označit, zda bylo pro to, aby ji mohl použít, potřeba nějaké nerostné suroviny (at' už pro její získání, výrobu, transport, instalaci, možnost použití atd.). Pro záznam může být vytvořen i záznamový arch v podobě tabulky, kde se použité předměty zapisuji do řádků a jednotlivé prípady potřeby nerostných surovin do sloupců (výroba, transport...).

\section{Výuková aktivita č. 3: Srovnání vzniku přírodních a antropogenních hornin}

Popis: Tato pracovní aktivita souvisí s rozlišováním př́rodních a antropogenních materiálů a s porovnáním způsobu vzniku jednotlivých materiálů vzhledem k př́rodnímu cyklu hornin.

Materiál: Vzorky prírodních hornin a umělého materiálu. Z prírodních hornin mohou být použity napríklad slepenec, obsidián, galenit nebo pyrit, žula. Z antropogenních materiálů např́klad kus betonu, sklo, kov nebo slitina kovu a umělá hmota. Alternativou je předložení pouze prírodních materiálů $s$ tím, že antropogenní materiály žáci identifikují v okolí (např́klad v budově školy, na ulici, náměstí, při cestě do školy atd.). Poprípadě může být tato aktivita spojena s "geologickým mapováním" ulice, náměstí, městské čtvrti, kde je možné nalézt jak přírodní, tak antropogenní stavební a obkladové materiály.

Postup: Žáci by si nejprve měli zopakovat jednotlivé fáze cyklu hornin, jako je krystalizace vyvřelých hornin z magmatu, chemické a mechanické zvětrávání na zemském povrchu, transport zvětralin, třídění a opracování během transportu, usazování, zpevňování sedimentu, metamorfóza (přeměna), která může vést až k natavení a tvorbě taveniny, respektive nového magmatu. $K$ výše uvedeným jednotlivým fázím Ize přirovnat činnosti, které člověk vykonává během těžby, transportu a zpracování nerostných surovin. Např́klad: těžba $\approx$ eroze a zvětrávání, převoz $\approx$ transport zvětralin, úpravnictví surovin $\approx$ tř́dění a opracování během transportu, stavební činnost, tvorba hald a ukládání odpadů $\approx$ usazování, tvorba stavebních materiálů $\approx$ zpevňování sedimentů, metalurgické a petrurgické zpracování $\approx$ přeměna hornin a tavení. U předložených př́rodnin a antropogenních materiálů by se měli žáci pokusit alespoň přibližně porovnat způsoby jejich vzniku či výroby. 


\section{Výuková aktivita č. 4: Množství těžených nerostných surovin v ČR}

Popis: Nerostná surovinová základna každé země je většinou dávána do souvislosti s bohatstvím a ekonomickou prosperitou a konkurenceschopností. Na množství vytěžených nerostných surovin je však možné se podívat i z jiného úhlu pohledu - z hlediska množství člověkem extrahovaného a transportovaného horninového materiálu $z$ daného regionu za jeden rok.

Materiál: Hornická ročenka ČR, nebo alespoň jejich tabulkové přehledy. V současné době je na internetu dostupný tabulkový přehled z Hornické ročenky pro rok 2012 (http://www.cbusbs.cz/docs/rocenka10.pdf ). Možná je také práce se Statistickými ročenkami MŽP ČR, které ale nejsou tak podrobné. Pro srovnávání údajů je vhodné mít př́stup $\mathrm{k}$ internetovému vyhledávači.

Postup: $V$ přehledových tabulkách Hornické ročenky si žáci vyhledají informace týkající se celkové těžby nerostů, z nichž vypočítají celkové množství nerostných surovin vytěžených za jeden rok na území ČR (podle toho, se kterou ročenkou budete pracovat). Ve většině ročenek je uvedena těžba za více let, je tedy možné vypočítat celkové množství extrahovaného materiálu za delší období. Poté by se měli podívat na celkovou rozlohu plochy dobývacích prostorů a procentuálně ji porovnat s celkovou rozlohou ČR. Hornické ročenky také poskytují informace o délce důlních děl, žáci tedy mohou spočítat celkovou délku podzemních prostor. Aby si udělali lepší představu o této délce, mohou ji srovnat s nějakým jiným údajem, jako je např́klad vzdálenost dvou libovolných měst, nebo délka hranice ČR s okolními státy. Přehledové tabulky Hornické ročenky pro rok 2012 obsahují údaje o těžbě uhlí od roku 1876 až do současnosti, ze kterých Ize sestavit přehledný graf a spočítat, jaké celkové množství uhlí (černého i hnědého) již bylo v ČR od té doby odtěženo.

\section{Závěr}

Moderní člověk významným způsobem přetváří litosféru a zasahuje do přírodních procesů $v$ ní probíhajících. Proto je důležité, aby byl $v$ rámci environmentální výchovy věnován dostatečný prostor dopadům lidské činnosti na geologii a geomorfologii krajiny. Porozumění vztahů mezi lidskou činností a geologickými procesy vede k posílení mezipředmětových vztahů a umožnění komplexního pochopení dynamických souvislostí mezi ekosystémy $v$ dlouhodobém (geologickém) časovém měřítku.

\section{Poděkování:}

Tento příspěvek vznikl s podporou projektu GAJU 078/2013/S.

\section{Literatura}

- Alexander, W. F., \& McKInLEY, I. G. (1992). A Review of the Application of Natural Analogues in Performance Assessment: Improving Models of Radionuclide Transport in Groundwaters. Journal of Geochemical Exploration, 46(1), 83-115. Retrieved from http://linkinghub.elsevier.com/retrieve/pii/037567429290102E http://dx.doi.org/10.1016/0375-6742(92)90102-E

- Holbrook, A. W. J. A., \& J M, (2012). Is the Anthropocene an issue of stratigraphy or pop culture. GSA Today, 22(7), 60-61. 
- Crutzen, P. J., \& Stoermer, E. F. (2000). The "Anthropocene". Global Change Newsletter, 41, 17-18.

- Doney, S. C. (2010). The growing human footprint on coastal and open-ocean biogeochemistry. Science, 328(5985), 1512-1516. Retrieved from http://toxnet.nlm.nih.gov/cgi-bin/sis/search/r?dbs+hsdb:@term+@rn+124-38-9 pmid:20558706 http://dx.doi.org/10.1126/science.1185198

- Dvořáčková, S., \& Ryplova, R. (2012). Sonda environmentální gramotnosti studentů prírodovědně a ekologicky zaměřených oborů na Pedagogické fakultě ju. Envigogika, 7(3), Retrieved from http://www.envigogika.cuni.cz/index.php/Envigogika/article/view/77 http://dx.doi.org/10.14712/18023061.77

- Ellis, E. C., Goldewijk, K. K., Siebert, S., Lightman, D., \& Ramankutty, N. (2010). Anthropogenic tramnsformation of the biomes, 1700 to 2000. Global Ecology and Biogeography, 19, 589-606.

- Jirásek, J., Sivek, M., \& Láznička, P. (2010). Ložiska nerostů. Ostrava: Anagram.

- Johnson, A. B., \& Francis, B. (1980). Durability of Metals from Archeological Objects, Metal Meteorites and native Metals, Batelle Pacific Northwest Laboratiries Report No. PNL-3198. In: Anthropogenic analogues for geological disposal of high level and long lived waste. Final report. : International Atomic Energy Agency.

- Laciok, A., Rajlich, P., \& Palagyi, S. (2005) Anrhopogenic analogues in the Czech Republic - studies on glass and concrete materials. Anthropogenic analogues for geological disposal of high level and long lived waste. In Final Report (pp. 35-53). : International Atomic Energy Agency.

- Manichev, V., Demchenko, L., Zlobenko, B., Kadoshnikov, V., \& Spasova, L. (2005). The stability of the ancient metal and glass from archaeological sites of the northern prichernomor'e (ukraine) and their physical and chemical interactions with the burial environment. Anthropogenic analogues for geological disposal of high level and long lived waste. Final report of a coordinated research project 1999-2004.. Vienna, Austria: International Atomic Energy Agency.

- Suk, M. \& Matyášek, J., (2009). Antropogeneze v geologii. Skripta. Brno: Masarykova univerzita.

- Price, S. J., Ford, J. R., Cooper, A. H., \& Neal, C. (2011). Humans as major geological and geomorfphological agents in theAnthropocene: the significance of artificial ground in Great Brittain. Philosophical Transactions of the Royal Society A, 369(1938), 1056-1084. Retrieved from http://rsta.royalsocietypublishing.org/cgi/doi/10.1098/rsta.2010.0296 http://dx.doi.org/10.1098/rsta.2010.0296

- Raymo, M. (2012). The Age We Made 2/4. BBC Disovery Podcast, 29th Oct. 2012.

- Ruddiman, W. F., \& Thomson, J. S. (2001). The case for human causes of increased atmospheric $\mathrm{CH} 4$ over the last 5000 years. Quaternary Science Reviews, 20(18), 1769-1777. Retrieved from http://linkinghub.elsevier.com/retrieve/pii/S0277379101000671 http://dx.doi.org/10.1016/S0277-3791(01)00067-1 
- Ruddiman, W. F. (2003). The anthropogenic greenhouse era began thousands of years ago. Climat. Change, 61(3), 261-293. Retrieved from http://link.springer.com/10.1023/B:CLIM.0000004577.17928.fa http://dx.doi.org/10.1023/B:CLIM.0000004577.17928.fa

- Ryer, T. A., \& Langer, A. W. (1980). Thickness change involved in the peat-to-coal transformation for a bituminous coal of cretaceous age in central Utah. Journal of Sedimentary Petrology, 50(3), 987-992.

- Shukolyukov, A., \& Lugmair, G. W. (1998). Isotopic Evidence for the CretaciousTertiary Impactor and its Type. Science, 282(5390), 927-930. Retrieved from http://www.sciencemag.org/cgi/pmidlookup?view=long\&pmid $=9794759$ pmid:9794759 http://dx.doi.org/10.1126/science.282.5390.927

- Smith, B. D., \& Zeder, M. A. (2013). The onset of the Anthropocene. .

- Steffen, W., \&amp, P. J., Mcneill Crutzen,, \& J, (2007). The Anthropocene: are humans now overwhelming the great forces of nature. Ambio, 36(8), 614-621. Retrieved from http://www.scholaruniverse.com/ncbi-linkout?id=18240674 pmid:18240674 http://dx.doi.org/10.1579/00447447(2007)36[614:TAAHNO]2.0.CO;2

- Stinchcomb, G. E., Stewart, R. M., Messner, T. C., Nordt, L. C., Allen, D. S. G. A., \& P M, (2013). Using event. stratigraphy to map the Anthropocene - An example from the historic coalmining region in eastern. Pennsylvania, USA. Anthropocene.

- Stromberg, J. (2013). What is the Anthropocene and Are We in It? Smithsonian magazine. , Retrieved from http://www.smithsonianmag.com/sciencenature/What-is-the-Anthropocene-and-Are-We-in-It-183828201.html

- Syvitski, J. P. M. (2012). Anthropocene: An epoch of our making. Global Change, $78,12-15$.

- Syvitski, J. P. M., \& Kettner, A. (2013). Sediment flux and the Anthropocene. Philosophical Transactions of the Royal Society A, 369(1938), 957-975. Retrieved from http://rsta.royalsocietypublishing.org/cgi/doi/10.1098/rsta.2010.0329 http://dx.doi.org/10.1098/rsta.2010.0329

- Syvitski, J. P. M., VÖrÖsmarty, C., \&amp, A. J., Green Kettner, , \& P, (2005). Impact of humans on the flux of terrestrial sediment to the global coastal ocean. Science, 308(5720), 376-380. Retrieved from http://www.sciencemag.org/cgi/pmidlookup?view=long\&pmid $=15831750$ pmid:15831750 http://dx.doi.org/10.1126/science.1109454

- Tyrell, T. (2011). Anthropogenic modification of the oceans. Philosophical Transactions of the Royal Society A, 369(1938), 887-908. Retrieved from http://rsta.royalsocietypublishing.org/cgi/doi/10.1098/rsta.2010.0334 http://dx.doi.org/10.1098/rsta.2010.0334

- Vane, C. H., Chenery, S. R., Harrison, I., Kim, A. W., \& Moss-hayes, V. (2011). A JONES D.G., 2011: Chemical signatures of the Anthropocene in the Clyde estuary UK: sediment hosted $\mathrm{Pb}, 207 / 206 \mathrm{~Pb}$, Total petroleum hydrocarbon, polyaromatic hydrocarbon and polychlorinated biphenyl pollution records. Philosophical Transactions of the Royal Society A, 369(1938), 1085-1111. Retrieved from 
http://rsta.royalsocietypublishing.org/cgi/doi/10.1098/rsta.2010.0298 http://dx.doi.org/10.1098/rsta.2010.0298

- Weisman, A. (2009). Svět bez nás. Překlad Hana Loupová. Agro, Doko\&trade;án: Agro, Dokořán.

- Zalasiewicz, (2012). The Age We Made 4/4. BBC Disovery Podcas, 2nd Nov. 2012.

- Zalasiewicz, J., Williams, M., Fortey, R., Smith, A., Barry, T. L., Coe, A. L., . . . Stone, P. (2011). Stratigraphy of the Anthropocene. Stratigraphy of the Anthropocene. Philosophical Transactions of the Royal Society A, 369(1938), 10361055. Retrieved from http://rsta.royalsocietypublishing.org/cgi/doi/10.1098/rsta.2010.0315 http://dx.doi.org/10.1098/rsta.2010.0315

- Zhang, Z., Kong, Z., Wang, G., \& Ni, J. (2010). 2010: Anthropogenic and climatic impacts on surface pollen assemblages along a precipitation gradient in northeastern China. Global Ecology and Biogeography, 19, 621-631.

Mgr. Simona Dvořáčková, Ph.D. Zaměření: geologie. Pưsobiště: Katedra biologie Pedagogická fakulta Jihočeská univerzita $v$ Českých Budějovicích. E-mail: skralickova@pf.jcu.cz 